\title{
HERMENEUTIKA HADIS HUKUM
}

\author{
Wasman \\ IAIN Syekh Nurjati Cirebon \\ Jl. Perjuangan By Pass Sunyaragi Cirebon \\ Email:wasman1959@yahoo.co.id
}

\begin{abstract}
Abstrak
Artikel ini menawarkan pendekatan baru melalui sudut pandang hermeneutika dalam melakukan kajian kritis terhadap hadis. Kajian hadis dimulai dengan melakukan kritik, baik terhadap sanad maupun matan hadis, sebagaimana dijabarkan dalam ilmu hadis. Hal ini dilakukan untuk menguji otentisitasnya. Melalui perspektif hermeneutika, teks hadis yang merupakan produk masa lalu harus selalu berdialog dengan penafsir dan audiennya yang baru di sepanjang sejarah. Banyak sarjana kontemporer seperti Yūsuf al-Qaraḍāwì, Syuhudi Ismail dan Fazlur Rahman yang memperlihatkan pendekatan ini dalam karya-karya mereka. Tulisan ini menunjukkan relevansi dan signifikansi penggunaan hermeneutika filosofis sebagai kerangka acuan dalam memahami hadis. Tujuannya adalah untuk menemukan "makna hadis yang berarti" bagi kekinian kita. Logika praksisnya adalah mengkaji teks hadis secara tematik-komprehensif. Selanjutnya dilakukan upaya penentuan konteks sosiohistoris hadis, baik makro maupun mikro. Setelah ditemukan makna moraluniversalnya, makna-makna ini selanjutnya digeneralisasikan ke dalam konteks situasi baru yang plural, tetapi partikular.
\end{abstract}

Kata kunci: hadis, al-Qur'an, otentisitas, hermeneutika, makna yang berarti

\begin{abstract}
This article offers a new approach through the viewpoint of hermeneutics in conducting a critical assessment of the hadis. A study to hadis begins with criticism, both to the sanad and matn, as elucidated in the science of hadis. This was done to test its authenticity. Through the hermeneutic perspective, the text of hadis, which is a product of the past, must always take dialogues with the interpreters and the new audiences throughout history. Many contemporary scholars, like Yüsuf al-Qaradāwī, Syuhudi Ismail and Fazlur Rahman have demonstrated this approach in their works. This essay then shows the relevance and significance of employing the philosophical hermeneutics as a frame of reference in understanding hadis. Its goal is to find out "significant meaning of hadis" for our time. Its practical logics is to study a hadis text thematically and comprehensively, and to determine its socio-historical contexts, both in macro and micro level. Having found the universal moral meaning of a hadis, the meaning is then generalized to new present situations in the context of a pluralistic, but particular.
\end{abstract}

Keywords: hadis, al-Qur'an, otenticity, hermeneutics, significant meaning 


\section{A. Pendahuluan}

Hadis merupakan salah satu sumber hukum Islam yang diakui otoritatif setelah al-Qur'an. Di kalangan ulama Sunni, hadis atau sunnah adalah rujukan normatif yang menjadi penjelas (bayān) substansi al-Qur'an. Meskipun terdapat perbedaan menyangkut statusnya, yakni apakah ia dapat menjadi sumber independen dari al-Qur'an atau tidak, pada kenyataannya para ulama (Sunni) sepakat menyangkut signifikansi hadis sebagai sumber tasyri ${ }^{\circ}{ }^{1}$ Posisi demikian dengan jelas terekam dalam literatur fiqh mazhab. Yūsuf al-Qaradāwī dengan tepat mencatatnya:

Tanpa Sunnah kita tidak mengetahui kebanyakan ketentuan hukum dalam Islam baik menyangkut ibadah atau muamalah. Siapa saja yang membaca buku-buku fiqh Islam dari beragam mazhab, maka akan jelas baginya bahwa Sunnah adalah pegangan mayoritas ketentuan hukum. ${ }^{2}$

Dalam literatur ushul fiqh, para ulama (ușüliyyūnn) dengan tegas menjadikan penguasaan akan hadis sebagai salah satu kualifikasi mendasar dalam aktivitas ijtihad. ${ }^{3}$ Penguasaan hukum Islam, dalam perspektif ini, mau tidak mau harus dilandaskan atas pemahaman yang utuh tentang hadis, baik dari sisi teoritiknya maupun substansi doktrin hukumnya.

Sebagai sumber doktrin hukum, hadis (terutama ahädis al-ahkām) selama ini telah mendapat apresiasi yang luar biasa dalam bentuk kritik baik sanad maupun matan serta penjelasan materi muatannya (syurūh). Tulisan ini pada hakikatnya hendak menawarkan pendekatan baru melalui sudut pandang hermeneutika demi cara baca yang kritis dan lebih bertanggungjawab terhadap salah satu sumber hukum Islam ini.

\section{B. Uji Otentisitas Hadis}

Terdapat perbedaan yang sangat mendasar antara hadis dengan al-Qur'an. Perbedaan itu terutama terletak pada status periwayatan masing-masing sumber ajaran yang otoritatif itu. AlQur'an seperti diketahui keseluruhan ayat-ayatnya diriwayatkan secara mutawātir, karena itu status periwayatannya dinilai bersifat qat ${ }^{\prime} i$ alwurūd (diyakini orisinalitasnya berasal dari Tuhan yang diwahyukan kepada Nabi saw. melalui Malaikat Jibril dan hingga sekarang tidak ada perubahan). Sementara hadis mayoritasnya diriwayatkan secara $\bar{a} h \bar{a} d$, dan hanya sebagian saja yang diriwayatkan secara mutawātir. Karena itu status periwayatan hadis-hadis bersifat zann $\bar{i}$ al-wuru $\bar{d}$ (diduga berasal dari Nabi saw). ${ }^{4}$

Status periwayatan kedua sumber otoritatif di atas berimplikasi pada upayaupaya pemahaman terhadapnya. Ayatayat al-Qur'an karena telah disepakati berstatus qat' $\bar{i}$ al-wurüd, maka seorang penafsir tidak perlu lagi mempertanyakan status otentisitas ayat yang hendak dipahaminya, apakah ayat-ayat itu benarbenar merupakan wahyu Tuhan atau pun tidak, sebab telah ada kesepakatan bahwa yang hendak dipahaminya itu merupakan wahyu Tuhan. Yang dihadapi penafsir alQur'an adalah bagaimana ia mampu memahami ayat-ayat al-Qur'an yang dihadapinya itu, sehingga ia dapat menjelaskan ajaran Islam yang terkandung di dalam ayat-ayat al-Qur'an tersebut.

Sementara bagi orang yang hendak memahami hadis, ia akan dihadapkan pada persoalan otentisitas yang inheren pada hadis. Oleh karena itu, ia perlu terlebih dahulu mempertanyakan apakah hadis yang akan dipahaminya itu telah terbukti otentisitasnya berasal dari Nabi. Berdasar pada problem otentisitas yang demikian, maka minat untuk mengembangkan pemikiran tentang metode pemahaman hadis berbeda dengan minat yang berkembang pada 
upaya-upaya pengembangan metode pemahaman ayat-ayat al-Qur'an. Para pakar hadis acapkali disibukkan oleh masalah kesahihan atau validitas hadis. Jika seseorang yang hendak mengkaji alQur'an secara langsung melakukan kajian dan atau penafsiran tanpa disibukkan oleh otentisitasnya, sebaliknya para pengkaji hadis harus mengkaji otentisiasnya terlebih dulu sebelum melakukan penafsiran atau pemahaman terhadap hadis.

Pentingnya tahapan uji otentisitas ini didasarkan atas asumsi bahwa hadis mengalami tahap historis yang panjang sebelum ia kemudian menjadi wacana tekstual sebagaimana terdapat dalam kitab-kitab hadis. Ia mengalami tradisi pengalihan lisan (al-naql al-syafahi, transmisi verbal) dan tradisi pengalihan praktek (al-naql al-'amali, transmisi praktikal) sebelum ia memasuki tahap tradisi pengalihan tulisan (al-naql alkitabi, transmisi tekstual). Hal ini berbeda dengan al-Qur'an. Ia merupakan teks kitab suci yang otentik, karena pengalihan (transmisi) al-Qur'an adalah transmisi tekstual. Ia merupakan wahyu in verbatim, yakni persis sama dengan kata-kata yang diucapkan pertama kali karena ditulis segera setalah pewahyuan di bawah pengawasan dan koreksi Nabi sendiri. ${ }^{5}$ Dengan demikian, pengalihan (transmisi) al-Qur'an lebih memiliki validasi yang tinggi untuk menjamin keaslian teks dibandingkan dengan transmisi hadis. Artinya, otentisitas alQur'an teruji secara historis, sedangkan hadis pada tingkat kritik historis ini menghadapi problem menyangkut orisinalitas historisnya. ${ }^{6}$

Untuk itu sebelum memasuki tahap penafsiran dan pemahaman, problem otentisitas dan orisinalitas ini harus diselesaikan terlebih dahulu. Tidak mungkin akan terjadi pemahaman yang sahih bila tidak ada kepastian bahwa apa yang dipahami itu secara historis otentik. Jika tidak, maka sebuah pemahaman akan hadis bukan memberi petunjuk pada orang, sebaliknya akan menjerumuskan orang kepada kesalahan, meskipun dengan pemahaman yang benar. Keaslian teks keagamaan harus diuji berdasarkan atas kritik sejarah, bukan berdasarkan atas keyakinan, bukan pula kritik teologis, filosofis maupun mistis atau spiritual. $^{7}$

Dalam rangka menentukan validitas dan otentisitas hadis, para ulama kritikus hadis menetapkan lima unsur kaedah kesahihan, meliputi (1) sanad yang bersambung; (2) seluruh periwayat bersifat adil; (3) seluruh periwayat

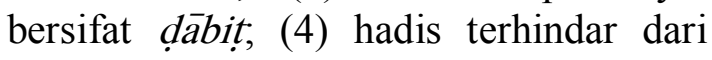
syużüz, dan (5) hadis terhindar dari 'illat. ${ }^{8}$

Kaidah ini merupakan kaedah yang komprehensif mengingat bahwa dengan kaedah tersebut, otentisitas dan validitas hadis tidak cukup hanya diuji melalui kritik sanad (naqd al-sanad) atau dikenal dengan kritik ekstern (al-naqd alkharijī) - meminjam dengan terminologi yang berkembang dalam disiplin sejarah-melainkan juga harus diuji melalui kritik matan (naqd al-matn) yang biasa disebut dengan kritik intern (alnaqd al-dakhili). ${ }^{9}$ Kaedah tersebut juga menunjukkan tingkat akurasi yang tinggi untuk membuktikan validitas dan otentisitas hadis. Bahkan Muhammad alGhazali menilai bahwa tidak ada dalam sejarah peradaban manusia tentang contoh akurasi dan kehati-hatian dalam menentukan validasi dan otentisitas data historis yang setara dengan kaedah kesahihan hadis tersebut. ${ }^{10}$

Pada tahap kritik historis ini, penggunaan kaedah kesahihan tersebut merupakan suatu yang niscaya, meskipun harus diakui pula bahwa pada tingkat operasional, penggunaan kaedah tersebut masih menghadapi beberapa problem. Misalnya, menyangkut parameter untuk menentukan bahwa seorang perawi adalah adil; sejauh mana tingkat kedábit-an seorang rawi dapat diukur dan sebagainya. Di samping itu, sejauhmana bias konflik teologis dan konflik politik 
dan konflik mazhab dalam kodifikasi dan sistematisasi juga merupakan titik yang harus dikritisi.

\section{Hermeneutika Hadis}

Setelah menentukan derajat otentisitas historis hadis, baru dilanjutkan pada pemahamana akan hadis, atau analisis isi, yakni pemahaman terhadap muatan makna hadis. Di sinilah hermeneutika akan digunakan. Tentu saja, penggunaan hermeneutika ini tidak menafikan khazanah keilmuan yang ada dalam 'ulüm al-hadis. Proses pemahaman hadis menggunakan dua tradisi keilmuan sekaligus, yakni tradisi hermeneutika dan tradisi kajian hadis.

\section{Pengertian Hermeneutika}

Hermaneutika berasal dari bahasa Yunani hermeneia (kata benda) yang kata kerjanya adalah hermeneuein yang berarti menafsirkan. Ada spekulasi historis bahwa kata ini berkaitan dengan nama dewa Yunani, Hermes. Ia adalah penghubung Sang Maha Dewa di langit yang membawa pesan kapada manusia di bumi. Sehingga Hermeneunein berarti menyampaikan pesan dan menyampaikan berita. ${ }^{11}$ Dalam konteks Islam, peran Hermes tak ubahnya seperti peran Nabi sebagai utusan Tuhan yang bertugas sebagai juru penerang dan penghubung untuk menyampaikan pesan dan menyampaikan berita. Dalam konteks Islam, peran Hermes tak ubahnya seperti peran Nabi utusan Tuhan yang bertugas sebagai juru penerang dan penghubung dan menyampaikan pesan dan ajaran Tuhan kepada manusia. ${ }^{12}$ Bahkan Hossein Nasr bespekulasi bahwa Hermes tidak lain adalah Nabi Idris as. ${ }^{13}$

Hermeneia sebenarnya memiliki pengertian yang luas mencakup "pembicaraan" (speech), penjelasan tentang sesuatu yang belum jelas menggunakan ekspresi bahasa "penerjemahan" (translation) dari suatu bahasa ke bahasa lain dan "penafsiran" (commentary, exegesis), mengeksplisitkan makna yang samar dengan bahasa yang jelas. Pengertian terakhir inilah yang pada perkembangan berikutnya lebih dikenal dibandingkan yang lain. Hermeneutika menjadi identik dengan penafsiran (yang dalam bahasa Latin dipakai kata interpretatio). ${ }^{14}$ Namun karena perubahan sejarah, hermeneutika kemudian mengalami penyempitan makna menjadi penafsiran teks tertulis yang berasal dari lingkungan sosial dan historis yang berbeda dengan lingkungan dunia pembaca. ${ }^{15}$

Hermeneutika berarti suatu ilmu yang merefleksikan tentang bagaimana suatu kata atau peristiwa yang terjadi pada masa lalu mungkin dapat dipahami dan secara eksistensial dapat bermakna di dalam situasi kekinian manusia. ${ }^{16}$ Hermeneutika dipergunakan untuk mendiskripsikan usaha menjembatani antara masa lalu dan masa kini. ${ }^{17}$ Dengan demikian hermeneutika mengarahkan agar teks masa lalu mempunyai arti sekarang dan di sini, sehingga teks tersebut mengarah secara terbuka menuju yang sekarang dan di sini. ${ }^{18}$

Jika diterapkan ke dalam studi hadis, hermeneutika dapat dipahami sebagai ilmu yang merefleksikan tentang bagaimana teks hadis sebagai wahana yang merekam event masa lalu mungkin untuk dipahami dan secara eksistensial dapat bermakna di dalam situasi kekinian kita. Ini berarti bahwa dalam studi hadis, sebut saja hermeneutika hadis, teks hadis yang merupakan produk masa lalu itu harus selalu berdialog dengan penafsir dan audiennya yang baru di sepanjang sejarah. Hermeneutika hadis bukannya pemindahan teks-teks ke dalam konteksnya yang baru secara semenamena, karena jika ini yang terjadi maka teks seakan diasumsikan turun dalam masyarakat yang statis dan vakum perubahan. Hermeneutika hadis juga bukan menenggelamkan teks dalam konteks kekiniannya secara semenamena, karena pengabaian teks akan menggugurkan hermeneutika itu sendiri. 
Hermeneutika hadis mensyaratkan adanya dialog secara intensif antara teksteks hadis sebagai warisan masa lalu dengan penafsir dan audiensnya masa kini. Ibarat gerakan, maka hermeneutika hadis bergerak dari masa kini dengan horizon kekinian ke masa lalu di mana teks hadis muncul dengan horizon masa lalunya. Selanjutnya, masa lalu dengan horizonnya bergerak ke masa kini dengan horizon kekiniannya. Pertemuan horizon masa lalu dan horizon masa kini inilah yang akan melahirkan dialog struktur triadic, yakni antara teks-teks hadis, penafsiran dan audiens, sehingga pada gilirannya melahirkan wacana penafsiran hadis yang lebih bermakna dan fungsional bagi kahidupan manusia pada segmen sejarah tertentu.

\section{Model-model Hermeneutika Hadis \\ Dalam konteks pemikiran} keagamaan di dunia Islam, seperti di Indonesia, penggunaan hermeneutika sebagai metode pemahaman terhadap teks keagamaan sempat menuai kontroversi: ada yang menolak untuk menggunakan metode itu karena dinilai bukan merupakan metode yang berkembang dan digunakan dalam tradisi keilmuan Islam. Tetapi ada juga kelompok yang menerima metode tersebut sebagai metode pemahaman terhadap teks-teks keagamaan.

$$
\text { Sebagai sebuah metode }
$$

pemahaman teks pada umumnya, hermeneutika absah digunakan, baik untuk memahami al-Qur'an maupun hadis. Penggunaan hermeneutika dalam memahami al-Qur'an maupun hadis telah dilakukan oleh beberapa pemikir Islam kontemporer. Di antara pemikir yang menggunakan hermeneutika dalam studi al-Qur'an adalah Fazlur Rahman, Farid Esack, Hassan Hanafi, Nașr Ḥamid Abū Zayd, dan Khaled Abou El Fadl. Sedang penggunaan hermeneutika dalam studi hadis antara lain oleh Yūsuf al-Qaraḍ̄āi, Syuhudi Ismail, dan Fazlur Rahman.
Dalam memahami dan menemukan signifikasi kontekstual hadis, alQaraḍāwì, misalnya, menganjurkan beberapa prinsip penafsiran hadis, antara lain: pertama, memahami sunnah berdasarkan petunjuk al-Qur'an. ${ }^{19}$ Hal ini didasarkan pada argumentasi bahwa alQur'an adalah sumber utama yang menempati hirarki tertinggi dalam keseluruhan sistem doktrinal Islam, sedangkan hadis adalah penjelas (bayān) atas prinsip-prinsip al-Qur'an. Logikanya, penjelasan tidak boleh bertentangan dengan petunjuk alQur'an. ${ }^{20}$

Kedua, menghimpun hadis yang topik bahasannya sama. Hal ini dimaksudkan agar makna sebuah hadis dapat ditangkap secara holistik, tidak parsial. Al-Qaraḍāwi mencontohkan hadis mengenai keharaman memanjangkan kain hingga ke tanah. Ketika hadis tersebut dipahami dengan mengkonfirmasikan kepada hadis-hadis lain yang mempunyai kesamaan topik, maka dapat ditarik makna yang lebih komprehensif yakni memanjangkan kain hingga ke tanah itu haram hukumnya jika dimaksudkan sebagai ekpresi kesombongan seseorang. Jika tidak dalam rangka kesombongan, maka tidak haram. ${ }^{21}$ Berdasarkan contoh tersebut alQaraḍāwi menyatakan bahwa mengambil makna teks suatu hadis tanpa memandang hadis-hadis lain yang berkaitan dengan topik yang dimaksud akan membuka peluang lebar-lebar bagi munculnya deviasi pemahaman terhadap hadis. ${ }^{22}$

Ketiga, pemahaman hadis berdasarkan latar belakang, kondisi dan tujuannya. Maksudnya adalah memperhatikan eksistensi hadis-hadis yang dipelajari sesuai dengan latar belakang khusus dan kaitannya dengan penyebab tertentu yang tertuang dalam teks hadis dan tersirat dari maknanya atau terbaca dari kenyataan yang melahirkan hadis yang bersangkutan. Dengan cara ini, orang yang mempelajari hadis akan menemukan makna hadis dan 
signifikansinya bagi kebutuhan historis si penafsir sehingga ia dapat menemukan solusi bagi problematika yang dihadapi dan mampu merefleksikan kemaslahatan yang menjadi tujuan pokok syari'at. ${ }^{23}$

Selanjutnya, al-Qaraḍāwī menekankan bahwa sebuah hadis memuat dua dimensi instrumental (wasilah) dan dimensi intensial (gāyah). Yang pertama jelas sangat rentan dengan tarikan perubahan ruang dan waktu sehingga bersifat temporal, sedang yang kedua bersifat permanen. Ketika seorang penafsir hadis tidak mampu membedakan kedua dimensi ini, maka ia akan terjebak pada kekeliruan. ${ }^{24}$

Di atas ini semua, al-Qaraḍ̄āi juga menekankan perlunya pendekatan linguistik, khususnya berkaitan dengan pembedaan makna hakiki dan makna majazi dari lafal-lafal hadis sesuai denga prosedur gramatikal bahasa Arab. ${ }^{25}$ Terkait dengan ini, seorang penafsir harus menggunakan studi historis terhadap makna lafal-lafal hadis yang sesungguhnya pada saat hadis yang bersangkutan muncul dan pergeseranpergeseran makna yang terjadi pada bentangan sejarah berikutnya. Hal ini penting karena menunjukkan makna lafal hadis itu sangat dimungkinkan berubahubah dari satu masa ke masa yang lain dari satu lingkungan kultural ke lingkungan kultural lainnya. ${ }^{26}$

Selain dalam karya-karya Yūsuf alQaraḍāwì, prinsip-prinsip hermeneutika hadis juga dapat ditemui dalam karyakarya Syuhudi Ismail, seorang pakar studi hadis kenamaan di Indonesia. Berangkat dari landasan normatif surat al-Maidah 3, Syuhudi Ismail menegaskan karakter Islam sebagai ajaran yang berlaku untuk semua umat manusia. Sebagai ajaran, Islam relevan dengan perubahan spasial dan temporal serta berlaku untuk semua umat dalam segala ras dan generasinya. Akan tetapi Syuhudi juga mengakui bahwa begitu Islam memasuki wilayah sejarah, ia akan terkena batasan-batasan kultural yang berlaku pada dunia manusia, sehingga Islam harus terejawantahkan dalam kehidupan praktis secara variatif sesuai dengan perbedaan ruang dan waktu. Berdasarkan latar belakang ini, Syuhudi membedakan antara ajaran Islam yang berwatak universal di satu sisi dan ajaran Islam yang berwatak temporal dan lokal di sisi lain. ${ }^{27}$

Berangkat dari landasan normatif pula, Syuhudi merumuskan posisi Nabi. Menurutnya, Nabi Muhammad saw. diutus sebagai rahmat bagi semesta alam. ${ }^{28}$ Pada bagian lain dinyatakan dalam al-Qur'an bahwa Nabi diutus untuk semua umat manusia. ${ }^{29}$ Ini berarti bahwa kehadiran Nabi Muhammad membawa kebajikan dan rahmat bagi umat manusia di segala waktu dan tempat. Akan tetapi, adalah kenyataan bahwa Nabi Muhammad hidup dalam batasan ruang waktu tertentu. Dengan demikian, hadis Nabi yang merupakan sumber otoritatif ajaran Islam juga berwatak universal di satu sisi dan di satu sisi lain berwatak temporal dan lokal. Universalitas, temporalitas dan lokalitas hadis Nabi tersebut juga ditentukan oleh fungsi dan perannya di dalam rentang sejarah hidupnya. Dalam sejarah, Nabi Muhammad berperan dalam banyak fungsi, antara lain sebagai Rasullulah dan kepala negara, pemimpin masyarakat, hakim dan juga pribadi. Ini menunjukkan bahwa penafsiran dan pemahaman terhadap hadis Nabi perlu dikaitkan dengan keanekaragaman fungsi dan peran Nabi ketika hadis itu muncul. ${ }^{30}$

Syuhudi Ismail tampaknya bukan orang pertama yang membedakan peran dan fungsi Nabi sebagaimana disebut di atas, karena jauh sebelum itu, al-Qarāîi juga telah membedakan peran dan fungsi Nabi sebagai imam yang agung, qāọi atau mufti, ${ }^{31}$ dan menurut Quraish Shihab, alQurafi inilah orang pertama yang pertama memilah-milah ucapan dan sikap Nabi Muhammad. ${ }^{32}$

Nabi Muhammad bagaimanapun hidup di tengah masyarakat dan berdialog 
dengan masyarakatnya, sehingga tidak jarang hadis Nabi merupakan respon terhadap peristiwa-peristiwa yang terjadi di tengah-tengah masyarakat, baik berkaitan dengan situasi umum maupun persoalan khusus yang dihadapi kepadanya. Realitas dan situasi umum serta persoalan-persoalan khusus yang dihadapi Nabi berkaitan dengan munculnya hadis ini, demikian tegas Syuhudi, sangat penting untuk diperhatikan dalam menafsirkan dalam sebuah hadis. ${ }^{33}$

Sementara itu, prinsip-prinsip hermeneutika hadis Syuhudi Ismail dapat disimak dalam kutipan berikut ini:

Segi-segi yang berkaitan dengan erat dengan diri Nabi dan suasana yang melatarbelakangi maupun menyebabkan terjadinya hadis tersebut mempunyai kedudukan penting dalam pemahaman suatu hadis. Mungkin saja suatu hadis tertentu lebih tepat dipahami secara tersurat (tekstual) sedang hadis tertentu lainnya lebih tepat dipahami secara tersirat (kontekstual). Pemahaman dan penerapan hadis secara tekstual dilakukan bila hadis yang bersangkutan, telah dihubungkan dengan segi-segi yang bersangkutan dengannya, misalnya latar belakang terjadinya, tetap menuntut pemahaman sesuai dengan apa yang tertulis dalam teks hadis yang bersangkutan dipahami dan diterapkan tidak sebagaimana maknanya yang tersurat (tekstual). ${ }^{34}$

Titik tekan hermaneutika hadis Syuhudi tampaknya lebih diarahkan pada pembedaan makna tekstual dan kontekstual hadis. Perbedaan ini dapat dilakukan dengan memperhatikan sisi-sisi linguistik hadis menyangkut gaya bahasa, seperti jawāmi ' al-kalim (ungkapanungkapan singkat namun padat makna), ${ }^{35}$ tamsil (perumpamaan), ${ }^{36}$ ungkapan simbolik, ${ }^{37}$ bahasa percakapan ${ }^{38}$ dan ungkapan analogi. ${ }^{39}$ Di samping itu, hermeneutika hadis juga harus melibatkan studi historis menyangkut peran dan fungsi Nabi serta latar situasional yang turut melahirkan sebuah hadis. $^{40}$

Sekarang kita masuk pada pemikiran hermenutika Fazlur Rahman. Menurut Fazlur Rahman, seorang Nabi adalah sosok yang sangat berkepentingan untuk mengubah sejarah sesuai dengan pola yang dikehendaki Allah. Dengan demikian, baik wahyu yang disampaikan Nabi maupun amal perbuatan Nabi tidak dapat terlepas dari situasi historis yang aktual pada masanya. Dalam kalimat sederhananya "Allah" berfirman dan Nabi bersaksi sesuai dengan, walaupun sudah barang tentu tidak hanya untuk, suatu konteks historis tertentu. ${ }^{41}$

Ini berarti bahwa walaupun bercirikan situasi tertentu, hadis harus menembus dan melampaui konteks historis tersebut. Dalam perspektif yang demikian dan dengan pendekatan yang tepat, para ahli hukum dan intelektual muslim dapat memandang bahwa karir kerasulan Muhmmad (sunnah-pen.), di samping al-Qur'an merupakan sumber yang mampu menjawab semua persoalan umat sepanjang bentangan sejarahnya. Akan tetapi Rahman menyayangkan justru masalah-masalah dasar menyangkut metode-metode dan hermaneutika ini tidak dibicarakan secara adil oleh kaum muslimin. ${ }^{42}$

Secara garis besar, sunnah Nabi lebih tepat jika dipandang sebagai sebuah konsep pengayoman (a general umbrella concept) dari pada bahwa ia mempunyai sebuah kandungan khusus yang bersifat spesifik secara mutlak. Alasannya adalah bahwa secara teoritik dapat disimpulkan secara langsung dari kenyataan bahwa sunnah adalah sebuah terma prilaku (behavioral term). Oleh karena itu di dalam prakteknya tidak ada dua buah kasus yang benar-benar sama latar 
belakang situasionalnya secara moral, psikologis dan material, maka sunnah tersebut harus dapat diinteprestasikan dan diadaptasikan. Sunnah Nabi, demikian tegas Rahman, lebih merupakan penunjuk arah (pointer in a direction) dari pada serangkaian peraturan-peraturan yang telah ditetapkan secara pasti (an exactly laid-out series of rules). ${ }^{43}$

Berdasarkan asumsi-asumsi ini, Rahman mengintroduksi teorinya tentang penafsiran situasional terhadap hadis. Ia menegaskan bahwa kebutuhan kaum muslimin dewasa ini adalah melakukan reevaluasi terhadap aneka ragam unsurunsur di dalam hadis dan reinterpretasinya yang sempurna sesuai dengan kondisi-kondisi moral-sosial yang sudah berubah pada masa kini. Hal itu hanya dapat dilakukan melalui studi historis terhadap hadis dengan mereduksinya menjadi sunnnah yang hidup dan dengan secara tegas membedakan nilai-nilai nyata yang dikandung dari latar belakang situasionalnya. ${ }^{44}$ Hadis-hadis, termasuk dalam hal ini hadis-hadis hukum, harus ditafsirkan menurut perspektif historisnya yang tepat dan menurut fungsinya yang tepat di dalam konteks historisnya yang jelas. $^{45}$

Hadis-hadis hukum, demikian lanjut Rahman, harus dipandang sebagi suatu masalah yang harus ditunjau kembali (a problem to be retreated) dan bukan dipandang sebagai hukum yang sudah jadi yang dapat secara langsung dipergunakan (a ready-made law). ${ }^{46}$ Penafsiran situasional melalui studi historis dalam rangka mencairkan hadishadis ke dalam bentuk "sunnah yang hidup" ini akan membuat kita mampu menyimpulkan norma-norma darinya. Untuk diri kita sendiri melalui suatu teori etika yang memadahi dan kemudian penumbuhan kembali hukumnya yang baru dari teori tersebut. ${ }^{47}$

Studi historis ini menurut Rahman sangat penting, karena hanya dengan memahami latar belakang yang terdiri atas hal-hal yang telah diketahui secara pasti tentang Nabi dan umat Islam awal (di samping al-Qur'an), kita dapat menafsirkan hadis. ${ }^{48}$ Dengan prinsipprinsip seperti ini, Rahman menolak ajakan "kembali kepada al-Qur'an dan Sunnah" secara tekstual dari Ibn Taymiyah yang menjadi isu sentral bagi gerakan-gerakan pembaharuan lainnya. Rahman menolak pemahaman hadis hanya dengan menggunakan perspektif masa lalu. Hadis-hadis sebagai warisan masa lalu menurutnya harus dipahami dengan menggunakan perspektif masa kini. Dalam kaitan ini Rahman dengan tegas menyatakan:

But this means not just a simple "return" to the Qur'an and the sunnah as they were acted in the past but a true understanding of them that would give us guidance to day. A simple return to the past is, of course a return to the graves. ${ }^{49}$

Menurut Rahman, bukan hanya kembali kepada al-Qur'an dan sunnah secara sederhana sebagaimana yang dilakukan pada masa lalu, melainkan suatu pemahaman yang benar terhadap keduanya yang akan memberikan arahan kepada kita dewasa ini. Kembali ke masa lampau secara sederhana, tentu saja, kembali ke liang kubur.

Uraian-uraian

tersebut menunjukkan bahwa penafsiran situasional cukup strategis. Hal itu dilakukan dengan memahami teks hadis Nabi kemudian memahami latar belakang situasionalnya, yaitu menyangkut situasi Nabi dan masyarakat pada periode Nabi secara umum, termasuk dalam hal ini adalah $a s b \bar{a} b$ al-wurūd. Di samping itu, juga dengan memahami petunjukpetunjuk al-Qur'an yang relevan. Dari sini akan dapat dipahami dan dibedakan nilai-nilai nyata atau sasaran hukumnya (ratio-legis) dari ketetapan legal spesifikasinya, dan dengan demikian dapat dirumuskan prinsip ideal moral dari 
hadis tersebut. Langkah berikutnya adalah penumbuhan kembali hukumnya, yakni prinsip ideal moral yang didapat tersebut diaplikasikan dan diadaptasikan dalam latar sosiologis dewasa ini. Inilah yang dimaksud Rahman dengan "pencairan" hadis menjadi "sunnah yang hidup". Dengan demikian, penafsiran situasional Rahman ini mengkombinasikan pendekatan historis dengan pendekatan sosiologis.

Metode studi hadis yang telah dirumuskan oleh beberapa pakar tersebut pada tingkat tertentu sebenarnya telah merefleksikan ide-ide hermeneutika. Dalam hermeneutika hadis, bagaimanapun prinsip-prinsip tersebut sangat penting untuk dipertimbangkan. Artinya, untuk menangkap makna teksteks hadis yang relevan dengan konteks historis kekinian sehingga bermakna dan fungsional untuk menjawab problemproblem hukum dan kemasyarakatan masa kini, prinsip-prinsip itu adalah niscaya.

Secara sederhana, beberapa prinsip dari para pakar tersebut dapat di simpulkan dalam beberapa poin sebagi berikut: pertama, prinsip konfirmatif, yakni, dalam penafsiran hadis, seorang penafsir harus selalu mengkonfirmasikan makna hadis dengan petunjuk-petunjuk al-Qur'an sebagai petunjuk tertinggi ajaran. Hal ini penting mengingat hadis berfungsi sebagai penjelas (bayān) bagi al-Qur'an. Bahkan Nurcholish Madjid menegaskan bahwa sunnah Nabi, khususnya segi-segi yang dinamik dan mendasar lebih banyak diketahui dari kitab suci al-Qur'an dari pada kumpulan kitab hadis. Pengkajian terhadap firmanfirman Allah akan memberikan gambaran yang utuh tentang siapa Nabi dan bagaimana garis sepak terjang beliau dalam hidup beliau baik sebagai pribadi maupun sebagai utusan Tuhan. ${ }^{50}$

Kedua, prinsip tematiskomprehensif. Artinya, teks-teks hadis tidak bisa dipahami sebagai teks yang berdiri sendiri-sendiri, melainkan sebagai kesatuan yang integral, sehingga dalam penafsiran suatu hadis, seseorang harus mempertimbangkan hadis-hadis lain yang memiliki tema yang relevan, sehingga makna yang dihasilkan lebih komprehensif.

Ketiga, prinsip linguistik, yakni bahwa oleh karena hadis Nabi terlahir dalam sebuah wacana kultural dan bahasa Arab, maka dalam penafsiran hadis, seseorang harus memperhatikan prosedur-prosedur gramatikal bahasa Arab.

Keempat, prinsip historik, yang menghendaki dilakukannya pemahaman terhadap latar situasional masa lampau di mana hadis terlahir baik menyangkut background sosiologis masyarakat Arab secara umum maupun situasi-situasi khusus yang melatar belakangi munculnya sebuah hadis. Termasuk dalam hal ini kapasitas dan fungsi Nabi ketika melahirkan hadis yang bersangkutan.

Kelima, prinsip realistik. Artinya bahwa, selain memahami latar situasional masa lalu di mana hadis muncul, seseorang juga memahami situasional kekinian dengan melihat realitas kaum muslimin, menyangkut kehidupan, problem, krisis dan kesengsaraan mereka. Ini berarti bahwa penafsiran terhadap hadis tidak bisa dimulai dari kevakuman, tetapi harus dari realitas yang kongrit.

Keenam, prinsip distingstif dan legis. Hadis-hadis Nabi tidak bisa hanya dipahami sebagai kumpulan hukum (compendium of law) belaka, tetapi lebih dari itu, ia mengandung nilai-nilai etis yang lebih dalam. Untuk itu seorang penafsir harus mampu menangkap dengan jelas nilai-nilai etis yang hendak diwujudkan oleh sebuah teks hadis dari nilai-nilai legisnya. Hal ini sangat penting mengingat kegagalan dalam menangkap makna etis dari makna legis hadis akan berakibat pada kegagalan menangkap makna hakiki dari hadis itu.

Ketujuh, prinsip distingsi instrumental dan intensional, yaitu bahwa 
hadis memiliki dua dimensi, yakni dimensi instrumental (wasīlah) yang bersifat temporal dan praktikular di satu sisi dan dimensi intensional (gāyah) yang bersifat permanen dan universal di sisi lain. Pada titik ini, seorang penafsir harus mampu membedakan antara cara yang ditempuh Nabi dalam menyelesaikan problematika hukum dan kemasyarakatan pada masanya dan tujuan asasi yang hendak diwujudkan Nabi ketika memunculkan hadisnya itu. Dimensi instrumantal (cara), karena menyangkut segmen masyarakat tertentu dalam dimensi ruang dan waktu tertentu, maka bersifat temporal dan partikular, sementara dimensi intensional (tujuan) jelas tidak terpengaruh oleh perubahan ruang dan waktu. Dalam pemahaman hadis Nabi, yang sangat ditekankan adalah realisasi tujuan ini, meskipun cara yang ditempuh bisa jadi berbeda satu sam lain, bahkan berbeda dengan cara Nabi.

\section{Hermeneutika Filosofis: Sebuah Upaya Menemukan "Makna Hadis yang Berarti"}

Tulisan ini mengajukan hermeneutika filosofis sebagai acuan dalam memahami hadis, terutama hadishadis hukum. Tujuannya tentu saja untuk menemukan "makna hadis yang berarti" bagi kekinian kita. Namun sebelum menemukan makna yang berarti itu bagi kekinian kita, terlebih dulu kita harus menemukan makna yang berarti bagi realitas masa lalu. Untuk menemukan makna yang berarti bagi realitas masa lalu, yang disebut juga makna obyektif, penting juga digunakan hermeneutika obyektif, terutama model yang ditawarkan Fazlur Rahman. Untuk menemukan makna obyektif sebuah teks, Rahman menawarkan agar mengkaji teks di bawah sinaran historisnya. Selanjutnya mencari makna moral-universal teks, untuk kemudian dipraksiskan ke dalam konteks kekinian.

Logika praksis hermeneutika sebagaimana dimaksud di atas adalah dengan mengkaji teks secara tematikkomprehensif. Dalam arti lain, teks-teks hadis lain yang memiliki tema yang relevan dengan tema hadis yang bersangkutan dipertimbangkan, dengan tujuan untuk mendapatkan pemahaman yang lebih komprehensif. Setelah pemahaman tekstual terhadap hadis diperoleh melalui analisis isi, selanjutnya dilakukan upaya untuk menentukan konteks sosio-historis hadis-hadis. Dalam tahap ini, makna atau arti suatu pernyataan dipahami dengan melakukan kajian atas realitas, situasi atau problem historis di mana pernyataan sebuah hadis tersebut muncul. Dengan kata lain memahami hadis sebagai respons terhadap situasi umum masyarakat periode Nabi maupun situasi-situasi khususnya. Langkah ini mensyaratkan adanya suatu kajian mengenai situasi makro yakni situasi kehidupan secara menyeluruh di Arabia pada saat kehadiran Nabi baik mengenai kultur mereka. Setelah itu kajian mengenai situasi-situasi mikro, yakni asbāb wurūd al-hadis. Setelah ditemukan makna moral-universalnya, makna-makna ini selanjutnya digeneralisasikan ke dalam konteks situasi baru yang plural, tetapi partikular. ${ }^{51}$ Makna inilah yang dalam hermeneutika filosofis disebut "makna yang berarti”.

Sebagai penggagas hermeneutika filosofis, Gadamer berpendapat bahwa "memahami" adalah tindakan sirkuler antara teks dengan pembaca yang disebut the fusion of horisons, yakni mempertemukan pra-pemahaman pembaca dengan cakrawala atau horizon teks. ${ }^{52}$ Dalam fusi itulah, makna yang dicari bersemayam. Penekanan Gadamer pada fusi horizon dalam menemukan makna didasarkan pada argumen bahwa seseorang tidak mungkin bisa melepaskan diri dari tradisi dan prasangkanya dan apalagi memasuki tradisi dan prasangka orang lain. Menurut Gadamer, keduanya pasti hadir dalam setiap tindakan menafsir, lantaran 
keduanya merefleksikan keterkondisian historis umat manusia.

Dalam tataran praksis, Gadamer, menurut Sahiron, merumuskan hermeneutika filosofisnya dengan bertolak pada empat langkah: ${ }^{53}$ Langkah Pertama, kesadaran terhadap "situasi hermeneutik". Seorang pembaca harus menyadari bahwa situasi membatasi kemampuan seseorang dalam melihat dan membaca sebuah teks. Kedua, situasi ini membentuk "pra-pemahaman" bagi pembaca, dan pra-pemahaman ini selanjutnya mempengaruhi pembaca dalam mendialogkan teks dengan konteks. Walaupun ini sebagai syarat dalam membaca teks, Gadamer menyatakan bahwa, pembaca harus selalu merevisinya agar pembacaannya terhindar dari kesalahan. Ketiga, pembaca harus menggabungkan antara dua horizon: horizon pembaca dan horizon teks. Dalam penggabungan itu, pembaca harus terbuka pada horizon teks dan membiarkan teks memasuki horizon pembaca. Sebab, teks dengan horizonnya pasti mempunyai sesuatu yang akan dikatakan pada pembaca. Interaksi antara dua horizon ini dalam tradisi hermeneutika filosofis disebut "lingkaran hermeneutik". Dan langkah terakhir, keempat, menerapkan "makna yang berarti" dari teks bagi kondisi pembaca. Dalam arti, makna teks itu mempunyai arti bagi pembaca dalam situasi tertentu, dan bukan makna yang berarti bagi kehidupan penggagas.

Penggunaan hermeneutika
filosofis dalam studi hadis
dilatarbelakangi oleh kenyataan bahwa mayoritas hadis lahir sebagai respon atas situasi dan kondisi tertentu, sehingga makna yang berarti dari hadis-hadis itu tentu saja sesuai dengan situasi dan kondisinya. Begitu juga bagi para pensyarah hadis. Makna yang berarti dari hadis-hadis itu tentu saja sesuai dengan kondisi mereka. Apa yang mereka temukan dari hadis-hadis itu adalah makna yang berarti bagi mereka, dan sangat mungkin bukan makna yang berarti bagi kita. Oleh karena situasi dan kondisi kita berbeda dengan situasi dan kondisi saat hadis-hadis itu muncul, dan atau disyarahi oleh para muhaddis, maka seharusnya kita juga melakukan pemahaman atau men-syarah-i hadishadis itu untuk menemukan makna yang berati bagi situasi dan kondisi kekinian kita.

Agar makna yang berarti bagi kondisi kekinian kita bisa ditemukan, maka diperlukan suatu kajian yang cermat terhadap situasi kekinian dan analisis berbagai realitas yang dihadapi pembaca, sehingga kita dapat menilai situasi kekinian dan mengubah kondisinya sejauh diperlukan dan menentukan prioritas-prioritas baru untuk bisa mengimplementasikan nilai-nilai hadis secara baru pula.

Penafsiran dan pemahaman hadis dengan pendekatan yang seperti ini jelas akan melahirkan wacana hadis yang baru, dinamis dan kreatif, sehingga normanorma dan ideal-ideal sunnah Nabi dapat direalisasikan secara progresif di dalam aneka ragam fenomena dan lingkungan sosial. Karena itu ia senantiasa dapat mencari bentuk-bentuk yang baru dan segar bagi realisasi dirinya. Dengan demikian hadis tidak bisa lagi menjadi wacana yang statis melainkan menjadi sunnah yang hidup.

\section{E. Penutup}

Sebagai sumber kedua hukum Islam, hadis diklaim mempunyai otoritas yang menghendaki kepatuhan setiap muslim. Namun, berbeda dengan alQur'an, ketaatan terhadap hadis dilakukan setelah serangkaian proses yang sarat kritik dilalui. Sebelum sebuah hadis dapat dipahami dan kemudian diamalkan, ia harus terlebih dahulu diuji otentitas dan orisinalitasnya, bahwa ia benar-benar berasal dari Nabi Muhammad saw. Ulama hadis telah menyuguhkan metode kritik yang secara historis diakui reliable, yaitu melalui 
kritik sanad (atau kritik ekstern) dan kritik matan (kritik intern). Pemahaman hadis dapat ditempuh setelah hadis secara sanad dan matannya diakui otentisitasnya.

Melalui perspektif hermeneutika, teks hadis yang merupakan produk masa lalu harus selalu berdialog dengan penafsir dan audiennya yang baru di sepanjang sejarah. Hermeneutika hadis bukannya pemindahan teks-teks ke dalam konteksnya yang baru dan menenggelamkan teks dalam konteks kekiniannya secara semena-mena. Hermeneutika hadis mensyaratkan adanya dialog secara intensif antara teks-

\section{Catatan Akhir:}

${ }^{1}$ Untuk diskusi terbaru tentang persoalan dan perbedaan menyangkut penerimaan otoritas hadis, lihat Aisha Y. Musa, Hadith as Scripture: Discussions on the Authority of Prophetic Traditions in Islam (New York: Palgrave Macmillan, 2008).

${ }^{2}$ Yūsuf al-Qaraḍāwī, Madkhal li Dirāsah al-Syari'‘ah al-Islämiyyah̆ (Beirut: Mu'assasah alRisālah, 1993), hlm. 44.

${ }^{3}$ Lihat Muhammad ibn 'A Irsyād al-Fuhūil ilà Tahqīq al-Haqq min 'Ilm alUșūl, tahqiq oleh Abù Hafs Sami ibn al-'Arabi al-Asyarì (Riyad: Dār al-Fađ̣iah, 2000), II: $1027-$ 1030.

4 'Abd al-Wahhāb Khallāf, 'Ilm Ușūl alFiqh, cet. 12 (Kuwait: Dār al-Qalam, 1978), hlm. 34-35, 42-43.

5 Hassan Hanafi, Dirāsāt Islämiyyah (Kairo: Maktabat al-Anjila al-Miṣriyyah, 1987), hlm. 37.

6 Lantaran inilah, Maurice Bucaille, misalnya, meletakkan posisi studi kritik terhadap hadis sebanding dengan studi historis atas Bible, yakni keduannya memiliki problem orisinalitas yang sama. Menurutnya, Bibel tidak bisa disejajarkan dengan al-Qur'an, tetapi hanya dapat disejajarkan dengan hadis. Lihat Maurice Bucaille, Bibel, al-Qur'an dan Sain Modern, terj. H. M. Rasyidi (Jakarta: Bulan Bintang, 1978), hlm. 17.

${ }^{7}$ Hanafi, Dirāsāt Islāmiyyah, hlm. 1, 4-5.

${ }^{8}$ Lihat Abū 'Amr 'Usmān ibn 'Abd alRaḥmān ibn al-Ṣalāh, 'Ulūm al-Hadiss, cet. 2 (Madinah: Maktabah al-'Ilmiyyah, 1972), hlm. 10; Muhammad Jamāl al-Dīn al-Qāsimī, Qawāìd al-Tahdìs min Funūn Muștalah al-Hadis (Kairo: teks hadis sebagai warisan masa lalu dengan penafsir dan audiensinya masa kini. Dalam kesarjanaan Islam kontemporer, perspektif ini sebenarnya, disadari atau tidak, tampak dalam karyakarya sarjana semisal Yūsuf al-Qaraḍ̄āìi, Syuhudi Ismail dan Fazlur Rahman. Lebih dari upaya-upaya hermeneutis tersebut, tulisan ini telah menunjukkan relevansi dan signifikansi penggunaan hermeneutika filosofis sebagai acuan dalam memahami hadis. Tujuannya adalah untuk menemukan "makna hadis yang berarti" bagi kekinian kita.

'Isa al-Halabiy, t.t.), hlm. 79; Abū al-Faḍl Muhammad ibn Muhammad 'Ali Farisì, Jawāhir al-Ușūl fì 'Ilm Hadìs al-Rasūl (Beirut: Dār alKutub al-'Ilmiyyah, 1992) hlm. 33.

9 Șalāh al-Dín ibn Ạ̣mad al-Adlabí, Manhaj Naqd al-Matn 'inda 'Ulamā' al-Hadis alNabawī (Beirut: Dār al-Āfāq al-Jadidah,1983), hlm. 31; M. Syuhudi Ismail, Hadis Nabi Menurut Pembela, Pengingkar dan Pemalsuannya (Jakarta: Gema Insani Press, 1995), hlm. 72.

${ }^{10}$ Muhammad al-Ghazali, Studi Kritis atas Hadis Nabi saw.: Antara Tekstual dan Kontekstual, terj. Muhmmad al-Baqir, cet. 6 (Bandung: Mizan, 1998), hlm. 26.

11 James M. Robinson, "Hermeneutic Since Barth", dalam The New Hermeneutic, ed. James M. Robinson dan Johan B. Cobb (New York: Harper and Row Publisher, 1964), hlm. 1; Lawrence K. Schmidt, Understanding Hermeneutics (Durham: Acumen, 2010), hlm. 6.

${ }_{12}$ Komaruddin Hidayat, Memahami Bahasa Agama: Sebuah Kajian Hermeneutika (Jakarta: Paramadina, 1996), hlm. 13. Lihat juga W. Poespoprodjo, Intepretasi: Beberapa Catatan Pendekatan Filsafatinya (Bandung: Karya Remaja, 1987), hlm. 91.

13 Seyyed Hosein Nasr, Knowledge and Sacred (t.t: State University Press, 1989), hlm. 71.

${ }_{14}$ Lawrence K. Schmidt, Understanding Hermeneutics, hlm. 6. Meskipun terdapat sinonimitas antara hermeneutika dengan penafsiran, tetapi pada hakekatnya terdapat nuansa yang berbeda, yakni yang pertama menunjukkan pada teori dan metodologi penafsiran sedang yang kedua berkaitan dengan aspek praksisnya. Dengan kata lain, yang pertama adalah exegesis theoretica sedang yang terakhir exegesis praktica. Lihat Robinson, "Hermeneutic", hlm. 2-6 dan 10. 
15 C. Varhaak dan R. Haryono Imam, Filsafat Ilmu pengetahuan: Telaah Cara Kerja Ilmu-ilmu, cet. 2 (Jakarta: Gramedia Pustaka Utama, 1991), hlm. 175.

$$
16 \text { Carl Braaten, History of }
$$

Hermaneuitics (Philadelpia: Fortreess, 1966), hlm. 131.

${ }^{17}$ Farid Essack, "Quranic Hermeneutic: Problem and Prospects", The Muslim World 83, 2 (1993), hlm. 122.

${ }_{19}^{18}$ Ibid., hlm. 177. memahami hadis berdasarkan petunjuk al-Qur'an ini bukan orisinal sebagai gagasan al-Qaraḍāwi. Pemikiran-pemikiran lain pada umumnya memiliki gagasan yang sama. Muhammad alGhazāli misalnya dalam karyanya al-Sunnah alNabawiyyah bayna Ahl al-Fiqh wa Ahl al-Hadis menyediakan hampir keseluruhan babnya untuk menegaskan betapa pemahaman terhadap hadis Nabi harus mempertimbangkan petunjukpetunjuk al-Qur'an.

${ }^{20}$ Yūsuf al-Qarādāwīi, Kayfā Nata'amal ma'a al-Sunnah al-Nabawiyyah: Ma'ālim wa Dawābịt (USA: al-Ma'had al-Alami li al-Fikr alIslāmī, 1990), hlm. 93.

${ }^{21}$ Ibid., hlm. 103-108.

${ }^{22}$ Ibid., hlm. 108.

${ }^{23}$ Lihat kembali ibid., hlm.125.

${ }^{24}$ Lihat ibid., hlm. 139.

${ }^{25}$ Lihat ibid., hlm. 155.

${ }^{26}$ Ibid., hlm. 179.

${ }^{27}$ Lihat Syuhudi Ismail, Hadis Nabi yang Tekstual dan Kontekstual: Tela'ah Ma'ani alHadis tentang Ajaran Islam yang Universal Temporan dan Lokal (Jakarta: Bulan Bintang, 1994), hlm. 3-4.

${ }^{28}$ Lihat QS. 21: 107.

${ }^{29}$ Lihat QS. 34: 28.

${ }^{30}$ Ismail, Hadis Nabi, hlm. 4. Fungsi Muhammad sebagai Rasul dan kepala negara dapat dilihat secara lebih rinci pada W. Montgomery Watt, Muhammad: Prophet and Statesman (London: Oxford University Press, 1969).

31 Lihat Syihāb al-Dīn al-Qarāfí, alFurūq (Kairo: Dār Ihyā' al-Kutub, 1344 H), I: 206.

32 Lihat M. Quraish Shihab, "Kata Pengantar" untuk edisi Indonesia atas karya Muhammad al-Ghazali, Studi Kritis atas Hadis Nabi saw., hlm. 9. hlm. 5 .

33 Lihat Syuhudi Ismail, Hadis Nabi,

\footnotetext{
${ }^{34}$ Ibid., hlm. 6

${ }^{35}$ Ibid., hlm. 10-13.

${ }^{36}$ Ibid., hlm. $13-17$.

${ }^{37}$ Ibid., hlm. $18-21$.

${ }^{38}$ Ibid., hlm. $22-27$.
}

${ }^{39}$ Ibid., hlm. $29-30$.

${ }^{40}$ Ibid., hlm. $33-68$.

${ }^{41}$ Fazlur Rahman, Islamic Methodology in History (Karachi: Central Institute of Islamic Research, 1965), hlm. 10.

${ }^{42}$ Fazlur Rahman, Islam and Modernity: Transformation of Intellectual Tradition (Chicago: The University of Chicago, 1984), hlm. 2.

12.

${ }^{43}$ Rahman, Islamic Methodology, hlm.

${ }^{44}$ Ibid., hlm. $77-78$.

${ }^{45}$ Ibid., hlm. 78.

${ }^{46}$ Ibid.

${ }^{47}$ Ibid., hlm. 80.

${ }^{48}$ Ibid., hlm. 81

${ }^{49}$ Ibid., hlm. 143.

50 Nurcholis Majid, "Pergeseran Pengertian 'Sunnah' ke 'Hadis': Implikasinya dalam Pengembangan Syari'ah," dalam Kontekstualisasi Doktrin Islam dalam Sejarah, ed. Budhy Munawar Rachman (Jakarta: Paramadina, 1997), hlm. 214.

${ }^{51}$ Itu tidak lain, karena setiap pernyataan Nabi harus diasumsikan, memiliki tujuan moralsosial yang bersifat universal. Rahman, Islam and Modernity, hlm. 6

52 Hermeneutika filosofis Gadamer tertuang dalam karya monumentalnya, Truth and Method. Lihat ulasannya dalam Lawrence K. Schmidt, Understanding Hermeneutics, hlm. 112114.

53 Lihat dalam Sahiron Syamsuddin, "Integrasi Hermeneutika Hans George Gadamer ke dalam Ilmu Tafsir? Sebuah Proyek Pengembangan Metode Pembacaan al-Qur'an pada Masa Kontemporer", Makalah dalam Annual Conference Kajian Islam oleh Dipertais Depag RI di (Bandung tgl. 26-30 Nopember 2006).

\section{DAFTAR PUSTAKA}

Al-Adlabī, Salāh al-Dīn ibn Ahmad. Manhaj Naqd al-Matn 'inda 'Ulamā', al-Hadis al-Nabawì. Beirut: Dār al-Āfāq al-Jadidah, 1983.

Braaten, Carl. History of Hermaneuitics. Philadelpia: Fortreess, 1966.

Bucaille, Maurice. Bibel, al-Qur'an dan Sain Modern, Terj. H. M. Rasyidi. Jakarta: Bulan Bintang, 1978.

Esack, Farid. "Quranic Hermeneutic: Problem and Prospects", The Muslim World 83, 2 (1993). 
Al-Farisī, Abū al-Fadl Muhammad ibn Muhammad 'A īi. Jawāhir al-Ușūl fì 'Ilm Hadis al-Rasūl. Beirut: Dār al-Kutub al-'Ilmiyyah, 1992.

Al-Ghazali, Muhammad. Studi Kritis atas Hadis Nabi saw.: antara Tekstual dan Kontekstual, terj. Muhmmad al-Baqir. Bandung: Mizan, 1998.

Hanafí, Hassan. Dirāsāt Islāmiyyah. Kairo: Maktabat al-Anjila alMișriyyah, 1987.

Hidayat, Komaruddin. Memahami Bahasa Agama: Sebuah Kajian Hermeneutika. Jakarta: Paramadina, 1996.

Ismail, M. Syuhudi. Hadis Nabi Menurut Pembela, Pengingkar dan Pemalsuannya. Jakarta: Gema Insani Press, 1995. Hadis Nabi Yang Tekstual dan Kontekstual: Tela'ah ma'ani alHadis tentang Ajaran Islam yang Universal Temporan dan Lokal. Jakarta: Bulan Bintang, 1994.

Khallāe, 'Abd al-Wahhāb. 'Ilm Ușūl alFiqh. Kuwait: Dār al-Qalam, 1978.

Madjid, Nurcholish. "Pergeseran Pengertian 'Sunnah' ke 'Hadis': Implikasinya dalam Pengembangan Syari'ah", dalam Budhy Munawar Rachman (ed.), Kontekstualisasi Doktrin Islam dalam Sejarah. Jakarta: Paramadina, 1997.

Musa, Aisha Y. Hadith as Scripture: Discussions on the Authority of Prophetic Traditions in Islam. New York: Palgrave Macmillan, 2008.

Nasr, Seyyed Hosein. Knowledge and Sacred. Ttp.: State University Press, 1989.

Poespoprodjo, W. Intepretasi: Beberapa Catatan Pendekatan Filsafatinya. Bandung: Karya Remaja, 1987.

Al-Qāsimī, Muhammad Jamāl al-Dīn. Qawā'id al-Tahdìs min Funūn
Mustalah al-Hadis. Kairo: 'Isa alHalabiy, t.t.

Al-Qarāfî, Syihāb al-Dīn. al-Furūq, 2 juz. Kairo: Dār Ihyyā' al-Kutub, 1344 $\mathrm{H}$.

Al-Qaraḍ̄āì, Yūsuf. Kaifā Nata'amal ma'a as-Sunnah an-Nabawiyah: Ma'ālim wa Dawābiț. USA: alMa'had al-Alami li al-Fikr alIslāmì, 1990.

Madkhal li Dirāsah alSyarī'ah al-Islämiyyah. Beirut: Mu'assasah al-Risālah, 1993.

Rahman, Fazlur. Islam and Modernity: Transformation of Intellectual Tradition. Chicago: The University of Chicago, 1984. Islamic Methodology in History. Karachi: Central Institute of Islamic Research, 1965.

Robinson, James M. "Hermeneutic since Barth". Dalam The New Hermeneutic. Ed. James M. Robinson dan Johan B. Cobb. New York: Harper and Row Publisher, 1964.

Al-Ṣalāh, Abū 'Amr 'Uśmān ibn 'Abd alRaḥmān ibn. 'Ulūm al-Hadis. Madinah: Maktabah al-'Ilmiyyah, 1972.

Shihab, M. Quraish. "Kata Pengantar" dalam Muhammad al-Ghazali. Studi Kritis atas Hadis Nabi saw.: antara Tekstual dan Kontekstual, terj. Muhmmad al-Baqir. Bandung: Mizan, 1998.

Schmidt, Lawrence K. Understanding Hermeneutics. Durham: Acumen, 2010.

Syamsuddin, Sahiron. "Integrasi Hermeneutika Hans George Gadamer ke dalam Ilmu Tafsir? Sebuah Proyek Pengembangan Metode Pembacaan al-Qur'an pada Masa Kontemporer". Makalah dalam Annual Conference Kajian Islam oleh Dipertais Depag RI di (Bandung tgl. 26-30 Nopember 2006). 
Al-Syawkāni, Muhammad ibn 'ATi. Irsyād al-Fụhūl ilā Tahquiqq alHaqq min 'Ilm al-Ușūl. Tạqī oleh Abū Hafs Samì ibn al-'Arabì al-Asyari. 2 jilid. Riyad: Dār alFaḍiah, 2000.
Varhaak, C. dan R. Haryono Imam. Filsafat Ilmu pengetahuan: Telaah Cara Kerja Ilmu-ilmu. Jakarta: Gramedia Pustaka Utama, 1991.

Watt, W. Montgomery. Muhammad: Prophet and Statesman. London:Oxford University Press, 1969. 